\title{
UTILIZATION OF A CHEMICAL-MECHANICAL PULP WITH IMPROVED PROPERTIES FROM POPLAR WOOD IN THE COMPOSITION OF PACKING PAPERS
}

\author{
$\underline{\text { R. Boeva-Spiridonova }}{ }^{a^{*}}$, E. Petkova ${ }^{a}$, N. Georgieva ${ }^{a}$, L. Yotova $^{a}$, and I. Spiridonov ${ }^{a}$ \\ The aim of the present work is to obtain a chemical-mechanical pulp \\ (CMP) from poplar wood with improved properties, to be used in packing \\ papers in place of more expensive softwood or hardwood pulp. For \\ improving the CMP quality indicators, a preliminary treatment of the pulp \\ has been carried out with a mixture of oxidizing enzymes produced from \\ Phanerochaete chrysosporium, including lignin peroxidase, manganese \\ peroxidase, and laccase. The two types of fiber materials obtained were \\ double-stage bleached and then ground to $30^{\circ} \mathrm{SR}$. It was found that \\ preliminary enzyme treatment yielded CMP with improved physical, \\ mechanical, and optical properties. The enzyme-pretreated CMP also \\ refined faster, thus reducing the electricity consumption. Bleached CMP \\ from poplar wood, obtained after preliminary enzyme treatment, could be \\ successfully utilized at levels up to $40 \%$ in the composition of various \\ packaging papers.
}

Keywords: Cellulose, Chemical-mechanical pulp, Paper, Production, Utilization, Poplar wood, Phanerochaete chrysosporium

Contact information: a: Department of Pulp, Paper and Printing Arts, University of Chemical Technology and Metallurgy, 8, Kl. Ohridski Blvd., 1756 Sofia, Bulgaria, *Corresponding author: Tel.: +359 28163307, E-mail address:r_boeva@abv.bg,neli@uctm.edu

\section{INTRODUCTION}

The production of high yield fiber materials (HYFM) can be considered to be desirable from the standpoint of higher wood utilization efficiencies and an introduction of more environmentally sound technologies, generating less pollution. Such fibers have found application in production of different types of papers and cardboards.

Paper is an inseparable part of the daily life of contemporary people. High yield fiber materials, together with conventional lower-yield cellulosic fibers, find wide application in production of numerous types of paper and cardboard. In order to increase the share of these materials it is necessarily to improve their physical, chemical, and optical properties. Practically, this can be realized through addition of various chemical reagents.

Biocatalytic reactions likewise have been applied to an increasing number of industrial processes. These processes allow for development of ecologically clean technologies. Preliminary wood treatment with different enzymes could lead to breaking down of various connections within fiber structures and to improving the delignification processes, helping to obtain fibrous intermediate products that can be used for the production of paper. 
Studies of lignin biodegradation have been carried out mostly using white-rot fungi, which produce extracellular lignin-modifying enzymes, such as laccases and peroxidases (lignin peroxidases and manganese peroxidases) (Moreira et al. 1997a,b; Bennet et al. 2002). One application of white-rot fungi and their oxidative enzymes is in biobleaching and biopulping for the preparation of papermaking pulps. In such applications, the new processes, involving biotransformation and bioremediation, have the potential to displace environmentally harmful chemicals, as well as saving mechanical pulping energy costs (Higuchi et al. 1989; Niku-Paavola 2002).

The aim of the present work is to obtain a bleached chemical-mechanical pulp (CMP) from poplar wood with improved properties, to be used in the composition of packing papers. The use of lignocellulose-degrading enzymes from the basidiomycete Phanerochaete chrysosporium strain in pulp treatment was studied.

\section{EXPERIMENTAL}

\section{Strain and Media}

The strain Phanerochaete chrysosporium, which has been deposited in the National Bank of Industrial Microorganisms and Cell Cultures, Bulgaria as strain N1038, was used in the experiment. The cultivation of Ph. chrysosporium was carried out in a medium as described by Georgieva et al. (2004). The sterile glucose solution $\left(20 \mathrm{~g} . \mathrm{dm}^{-3}\right)$ was sterilized separately and was added to the growth medium. All chemicals were supplied by Merck (Germany).

\section{Cultivation Conditions}

The strain Phanerochaete chrysosporium was cultivated 96 hours in a batch culture on a rotary shaker $\left(180 \mathrm{rpm}\right.$ at $\left.30^{\circ} \mathrm{C}\right)$. At the $48 \mathrm{th}$ hour of the culture development benzyl alcohol was added in concentration $0.5 \mathrm{~cm}^{3} \cdot \mathrm{dm}^{-3}$. It is supposed that benzyl alcohol acts as an inductor in producing lignin-degrading enzymes (laccase, lignin peroxidases, and manganese peroxidases), which are extracellular (Georgieva et al. 2006). The biomass was separated at the end of the cultivation, and the experiments on pulp treatment were conducted with the resulting culture liquid (CL). Furthermore, the culture liquid samples, obtained during the cultivation, were concentrated 5-fold in an ultrafiltration cell without the losses in activity during concentration. The enzyme activities were determined according Bonnarme and Jeffries (1990), and Coll et al. (1993). The strain Phanerochaete chrysosporium possibly produced three types of enzymes extracellularly, however, the presence of laccase might not be significant, based on work by Bonnarme and Jeffries (1990).

\section{Production of CMP}

The starting material utilized in this research for obtaining of a chemicalmechanical pulp was the poplar wood from the species Populus deltoides cultivar Onda, having an improved density (474kg.m ${ }^{-3}$ ) (Shamko 1989).

Two kind of fibrous materials were prepared. The first was CMP from poplar wood, following preliminary optimal treatment with $7 \% \mathrm{NaOH}$ plus $2 \% \mathrm{Na}_{2} \mathrm{~S}_{4}$ by $90^{\circ} \mathrm{C}$ 
and duration 120min, liquor-to-wood ratio 1:5 (Petkova et al. 2001). The second kind of CMP was prepared after the enzyme treatment of poplar chips before grinding according to the determined treatment.

Two kinds of the poplar chips were refined in a Sprout-Valdron laboratory mechanical refiner up to $12^{\circ} \mathrm{SR}$. CMP, BPSW and BPHW were refined separately in laboratory Jokro mill up to $40^{\circ} \mathrm{SR}$.

Twenty grams of the absolutely dry chips were placed in a flask, where $100 \mathrm{~cm}^{3}$ of a CL with total activity of $179 \mathrm{U} / \mathrm{mg}$ was added. The flasks were placed in a rotary shaker at $30^{\circ} \mathrm{C}$ and $\mathrm{pH}=4.5$, then continuous aeration and stirring were applied (Georgieva et al. 2004). After 120 hours treatment, the chips were washed sufficiently to reach a neutral $\mathrm{pH}$ level and were used for production of a chemical-mechanical pulp, as per the preliminary determined optimization regime: $\mathrm{NaOH}-7 \%, \mathrm{Na}_{2} \mathrm{~S}_{4}-2 \%$, temperature $90^{\circ} \mathrm{C}$, treatment duration $-120 \mathrm{~min}$, and liquor-to-wood ratio $-1: 5$. The CMP obtained after the preliminary set optimal conditions, according to methods described by Petkova et al. (2001), was bleached in two stages, employing $\mathrm{H}_{2} \mathrm{O}_{2}$ and rongalit $\mathrm{C}$ $\left(\mathrm{NaHSO}_{2} \cdot \mathrm{CH}_{2} \mathrm{O} \cdot 2 \mathrm{H}_{2} \mathrm{O}\right)$.

The reagents $\mathrm{Na}_{2} \mathrm{SiO}_{3}$ and $\mathrm{MgSO}_{4}$ were applied as stabilizers of the $\mathrm{H}_{2} \mathrm{O}_{2}$. $\mathrm{NaOH}$ was added to reach a pre-determined $\mathrm{pH}$ level. In order to chelate the metals ions, the pulp was treated with the complexing agent EDTA. The following fiber materials and chemical reagents have been used for production of the paper samples: bleached sulfate cellulose pulp from hardwood, delivered by plant "Svoliza" JSC - Svishtov city, and bleached cellulose pulp from softwood, imported from Russia.

The paper samples obtained had a basis weight of $60 \mathrm{~g} / \mathrm{m}^{2}$ and sizing level $1.5 \mathrm{~mm}$. Test sheets were obtained by means of a Rapid Kothen machine (Bulgarian Standard ISO 536).

\section{Analytical Measurements}

The bleaching effect of the treatments was measured by spectrophotometer (Gretag Macbeth Spectroeye) measurement of diffuse blue reflectance factor (Bulgarian Standard ISO Brightness 2470), determination of bursting strength (Bulgarian Standard ISO 2758) on Schopper - Daalen, Laboratory beating Jokro mill method - Bulgarian Standard ISO 5264-3, determination of tearing resistance by the Elmendorf method Bulgarian Standard ISO 1974, determination of drainability by the Schopper-Riegler method - Bulgarian Standard ISO 5267-1, and determination of tensile properties - part 2, constant rate of elongation method - Bulgarian Standard ISO 1924 - 2 .

\section{RESULTS AND DISCUSSION}

Enzymatic treatment is one of the newest and most promising methods for bleaching of cellulosic fiber materials, and related technology also has been applied during their production. In Table 1 are shown the data of physical and mechanical properties of CMP. 
The physical and mechanical properties of CMP were improved by the enzyme treatment of the wood. It was found that the tensile index was increased by $45 \%$. The tear index was increased by $35 \%$, and the burst index was increased by $9 \%$ (Table 1 ).

It was determined that the chips treated with enzyme were ground faster (refining time $-15 \mathrm{~min}$ ) in comparison with native CMP (refining time 30min). By enzyme treatment the refining time decreased up to $35 \%$. The positive effects of such enzymatic treatment include faster chip refining and increased brightness level of the chemicalmechanical pulp, obtained during the further bleaching. These benefits are explained by the complex action of the three enzymes, which facilitate the weakening of the connections between the lignin and the other wood components, as well as lignin modification and plasticization (Poppius - Levin et al. 1997). It is possible to separate part of the lignin after the chemical and mechanical treatment of wood during the CMP processing. CMP yield, obtained after enzymatic treatment, is lower, a finding that tends to confirm the above-mentioned conclusions (Table 1).

Table 1. Physical and Mechanical Properties of Chemical-Mechanical Pulp from Poplar Wood

\begin{tabular}{|c|c|c|}
\hline Properties & Native CMP & CMP treated with $\mathrm{CL}$ \\
\hline Tensile index, N.m. $\mathrm{g}^{-1}$ & 30.7 & 44.5 \\
\hline Tear index, $\mathrm{mN} \cdot \mathrm{m}^{2} \cdot \mathrm{g}^{-1}$ & 6.5 & 8.8 \\
\hline Burst index, $\mathrm{kPa} \cdot \mathrm{m}^{2} \cdot \mathrm{g}^{-1}$ & 2.3 & 2.5 \\
\hline Brightness, \% & 35.4 & 38.2 \\
\hline Yield, \% & 92.8 & 91.2 \\
\hline
\end{tabular}

Results of tests of paperboard properties are shown in Table 2.

Table 2. Physical and Mechanical Properties of Packaging Papers Produced from Chemical-Mechanical Pulp form Poplar Wood Treated with CL

\begin{tabular}{|c|c|c|c|c|c|}
\hline $\begin{array}{c}\text { Fiber composition, } \\
\%\end{array}$ & $\begin{array}{c}\text { Tensile index, } \\
\mathrm{N} \cdot \mathrm{m}^{-1}\end{array}$ & $\begin{array}{c}\text { Tear index, } \\
\mathrm{mN} \cdot \mathrm{m}^{2} \cdot \mathrm{g}^{-1}\end{array}$ & $\begin{array}{c}\text { Burst index, } \\
\mathrm{kPa} \cdot \mathrm{m}^{2} \cdot \mathrm{g}^{-1}\end{array}$ & $\begin{array}{c}\text { Brightness, } \\
\%\end{array}$ & $\begin{array}{c}\text { Opaque } \\
\%\end{array}$ \\
\hline $\begin{array}{c}100 \% \text { bleached } \\
\text { CMP }\end{array}$ & 42.8 & 5.9 & 2.1 & 55.5 & - \\
\hline $\begin{array}{c}100 \% \text { unbleached } \\
\text { CMP }\end{array}$ & 44.5 & 8.0 & 2.5 & 38.2 & - \\
\hline $\begin{array}{c}50 \% \text { BPSW } \\
50 \% \text { BPHW }\end{array}$ & 66.7 & 8.0 & 4.7 & 67.5 & 80.7 \\
\hline $\begin{array}{c}60 \% \text { BPSW, } \\
40 \% \text { BPHW }\end{array}$ & 68.50 & 8.0 & 4.4 & 66.8 & 82.0 \\
\hline $\begin{array}{c}60 \% \text { BPSW, } \\
30 \% \text { BPHW, } \\
10 \% \text { bleached CMP }\end{array}$ & 66.30 & 7.2 & 4.4 & 65.5 & 89.9 \\
\hline $\begin{array}{c}60 \% \text { BPSW, } \\
20 \% \text { BPHW, } \\
20 \% \text { bleached CMP }\end{array}$ & 61.85 & 6.4 & 4.0 & 63.9 & 90.6 \\
\hline $\begin{array}{c}60 \% \text { BPSW, } \\
10 \% \text { BPHW, } \\
30 \% \text { bleached CMP }\end{array}$ & 57.40 & 6.0 & 3.6 & 60.0 & 91.5 \\
\hline $\begin{array}{c}60 \% \text { BPSW, } \\
40 \% \text { bleached CMP }\end{array}$ & 54.80 & 5.8 & 3.4 & 59.6 & 93.2 \\
\hline
\end{tabular}


The CMP obtained from poplar wood chips, preliminarily treated with enzymes, after two stages of bleaching by $\mathrm{H}_{2} \mathrm{O}_{2}$ and rongalit $\mathrm{C}$, was applied for production of packaging paper, together with bleached sulfate softwood and bleached sulfate hardwood. This was done aiming to preserve the quantity of BPSW by replacement of BPHW with CMP obtained after enzyme treatment and two-step bleaching. It was observed that the increase of the CMP quantity in the packaging paper caused decreases in the breaking index and the tear index (Table 2).

Such decrease is more significant when the bleached pulp from hardwood is completely replaced by CMP. But even in that case, the parameters remained relatively high: tensile index $54.8 \mathrm{~N} \cdot \mathrm{m} \cdot \mathrm{g}^{-1}$ and tear index $-5.8 \mathrm{mN} \cdot \mathrm{m}^{2} \cdot \mathrm{g}^{-1}$. Figure 1 shows the changes of the tensile index as a function of the increase of the CMP in paper composition.

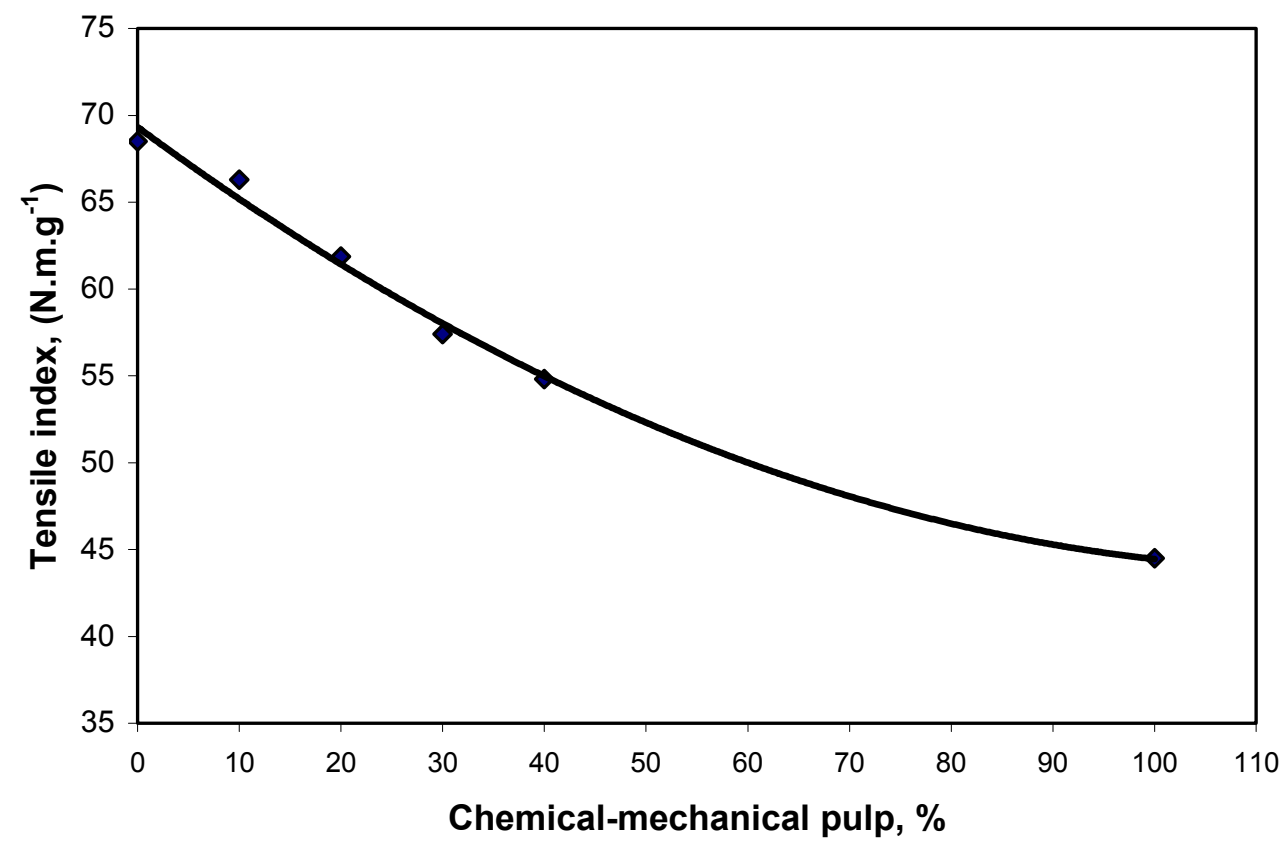

Fig. 1. Changes in the tensile breaking index, depending on the content of chemical-mechanical pulp, treated with $\mathrm{CL}$

The burst index remained relatively high $\left(3.4 \mathrm{kPa} \cdot \mathrm{m}^{2} \cdot \mathrm{g}^{-1}\right)$ at the fiber materials ratio of $60 \%$ BPSW and $40 \%$ bleached CMP. That means that the bleached sulfate pulp from hardwood could be successfully replaced by bleached chemical-mechanical pulp from poplar wood, obtained after preliminary enzyme treatment of the initial chips. The higher parameters of the initial CMP provide grounds for its application in the compositions of various packaging papers with improved properties. In this case, a decrease in the brightness level and increase in the opacity were also observed. The obtained packaging paper had a pleasant yellow color, and it can be successfully utilized for practical 
purposes, based in the initial results presented here. When the CMP content is $40 \%$, then a sharper decrease in the levels of the target parameters is observed.

\section{CONCLUSIONS}

1. The enzyme treatment of poplar chips was found to be compatible with the grinding process of CMP production.

2. The physical and mechanical properties of CMP were improved. The tensile index increased by up to $45 \%$, the tear index by up to $35 \%$, and the burst index by up to $9 \%$.

3. The quantity of improved CMP could reach up to 40 to $50 \%$ of the total fiber material. In this manner, at least some of the more expensive bleached sulfate pulp from hardwood can be displaced.

4. Bleached chemical-mechanical pulp from poplar wood, obtained after preliminary enzyme treatment, could be successfully utilized in the composition of various highquality packaging papers.

\section{Symbols used:}

CMP - chemical-mechanical pulp

CL - culture liquid

EDTA - ethylene-diamine tetra-acetic acid

${ }^{0} \mathrm{SR}$ - Degree Schopper- Riegler

rpm - revolution per minute

BPSW - bleached pulp from softwood

BPHW - bleached pulp from hardwood

HYFM - yield fiber materials HYFM

\section{REFERENCES CITED}

Bennet, J., Wunch, K., and Faison B. (2002). "Use of fungi biodegradation," In: Environmental Microbiology, Ch. Hurst (ed.), ASM Press Washington, D.C., 960971.

Bonnarme, P., and Jeffries, T. (1990). "Mn(II) regulation of lignin peroxidases and manganese-dependent peroxidases from lignin-degrading white rot fungi," Appl and Environ Microbiol 56:210-217

Coll, P., Fernandez-Abalos, J., Villanueva, J., Santamaria, R., and Perez, P. (1993). "Purification and characterization of a Phenoloxidase (Laccase) from the lignindegrading basidiomycete PM1 (CECT 2971)," Appl and Environ Microbiol 59:26072613

ISO 536:1998 - "Paper and board, Determination of grammage." 
Georgieva, N., Yotova, L., Betcheva, R., Hadzhiyska, H., and Valtchev, I. (2006).

"Biobleaching of lignin in linen by degradation with Trichosporron cutaneum R57,"

J. Univ. Chem. Technol. and Met. 41(2), 153-156.

Georgieva, N., Yotova, L., Valchev, I., Chadjiiska, Ch., and Arizanov, V. (2004).

"Biotransformation of lignin in linen by degradation with Phanerochaete chrysosporium," Proceedings Bioprocess System, Dec. 6-8, 4(10), Sofia.

Higuchi, T. (1989). "Mechanisms of lignin degradation by lignin peroxidase and laccase of white-rot fungi," Biogenesis and Biodegradation of Plant Cell Polymers, ACS Symposium Series, 399, 482-502.

Moreira, M. T., Feijoo, G., Sierra, R., Lema, J. M. and Field, J. A., (1997a). "Biobleaching of oxygen delignified Kraft pulp by several whtie rot fungal strains," Journal of Biotechnology 53, 237-251.

Moreira, M. T., Sierra, R., Feijoo, G., Lema, J. M. and Field, J. A. (1997b). “Manganese is not required for biobleaching of oxygen delignified kraft pulp by the white rot fungus Bjerkandera sp. Strain BOS55," Applied and Environmental Microbiology 63, 1749-1755.

Niku-Paavola, M. L., Tamminen, T., Hortling, B., Viikari, L. and Poppius-Levlin, K. (2002). "Reactivity of high and low molar mass lignin in the laccase catalysed oxidation," in Biotechnology in the Pulp and Paper Industry, Progress in Biotechnology, Viikari L. and Lantto R. (eds). Elsevier, Amsterdam, 21, 121-130.

Petkova, E., Boeva, R, and Litovski, Z. (2001).” Investigation of possibilities for obtaining of Chemical-Mechanical Pulp prom Poplar Wood", Celulose and Paper Journal, (3), 7-8.

Poppius-Levin, K., Wange, W., Tamminen, T., Horling, B., Viikari, L., and NikiPaovola, M. (1999). "Effects of Laccase /HBT Treatment on pulp and Lignin Structures," J. of Pulp and Paper Science, 25, (3), 90-94.

Shamko, V. E. (1989). "Yield Fiber Materials", Moskow., "Lesnaya promishlenost”, (in Russian).

Article submitted Nov. 26, 2006; First round of review completed: January 3, 2007;

Revised article accepted: Jan. 16, 2007; Published Jan. 19, 2007 